\title{
Identification and evaluation of landfill site selection criteria using a hybrid Fuzzy Delphi, Fuzzy AHP and DEMATEL based approach
}

\author{
Manoj Govind Kharat ${ }^{1} \cdot$ Sheetal Jaisingh Kamble ${ }^{1} \cdot$ Rakesh D. Raut $^{1}$ • \\ Sachin S. Kamble ${ }^{1}$
}

Received: 25 April 2016/ Accepted: 4 June 2016/Published online: 14 June 2016

(C) Springer International Publishing Switzerland 2016

\begin{abstract}
Landfill site selection is a complex multi-criteria and time consuming process. The present study aims to identify, evaluate, and prioritize the landfill site selection criteria and finally study the relationship between them, and the degree to which they affect or are affected by one another. In the first stage, experts' opinion was sought to select the relevant criteria and fuzzy Delphi Method (FDM) was employed to obtain the critical factors for selection of landfill sites. Next, the fuzzy Analytic Hierarchy Process (FAHP) was used to make pairwise comparisons of selected criteria by domain experts for assigning weights to the decision criteria and to calculate their importance degree. Finally, by considering the interrelationships among the criteria, Decision-making Trial and Evaluation Laboratory (DEMATEL) technique was applied to deal with the importance and causal relationships among them, and to recognize the influential criteria of landfill site selection. Obtained results show that, the criteria of sensitive area and intra-municipality are revealed to be the top two significant influences in selecting landfill sites. By identifying the relevant criteria, the structures and interrelationships, this study can offer an insight for decision makers to
\end{abstract}

Manoj Govind Kharat

manojgkharat@gmail.com

Sheetal Jaisingh Kamble

sheetaljkamble@gmail.com

Rakesh D. Raut

rakeshraut09@gmail.com

Sachin S. Kamble

sachinnitie06@gmail.com

1 National Institute of Industrial Engineering, National Institute of Industrial Engineering (NITIE), Powai,

Mumbai 400087, Maharashtra, India understand cause-effect relationships and allow to select suitable sites.

Keywords Landfill site selection - Sustainability criteria · Fuzzy logic $\cdot$ Multi-criteria decision-making $\cdot$ Fuzzy

Delphi · Fuzzy AHP · DEMATEL · Cause-effect relationship

\section{Introduction}

Municipal solid waste (MSW) management is one of the major problems in many urban cities worldwide. The problem is especially severe in developing countries where urbanization, rapid population growth, inadequate planning, and lack of scientific approach contribute to the poor state of solid waste management practices. Further, rapid urbanization and population increase have called for an improved waste management services i.e., an MSW facility should be environmentally and economically sound (technical point of view) as well as socially accepted (sociological perspective) (Ahmed and Ali 2006). MSW management is not only an environmental task, but encompasses several technical, socio-cultural and economic factors. MSW management includes various components as waste reduction, reuse, recycling, energy recovery, and disposal (Moeinaddini et al. 2010).

Safe disposal of waste is necessary for proper MSW management. Despite of negative environmental effects, in many nations, waste disposal using unsanitary landfilling and open dumping is in practice because it is simple and relatively inexpensive (Kim and Owens 2010). The siting of the safe, optimal landfill location is an important step which involves and affects the economic, ecological, and the environmental factors (Kouznetsova et al. 2007; 
Goorah et al. 2009). Inappropriate and unplanned siting of landfill facilities or lack of engineered protection measures can result in a number of social, economic, and environmental concerns such as release of leachate to the environment, emission of toxic and explosive landfill gases, dispersion of dust and odour as well as visual landscaping problems for adjacent residential areas (Looser et al. 1999; Kim et al. 2009; Moghaddas and Namaghi 2011). Undoubtedly, ideal and precise landfill site selection can mitigate various issues concerned with waste disposal. Therefore, selecting landfill sites that meet the environmental regulations, social, economic, technical factors and reduce the undesired impacts of current practices is the main priority for MSW management.

Landfill site selection is a challenging task as it involves multiple factors such as, technical, environmental, geological-hydrogeological, operational, economic, social and political (Sumathi et al. 2008; Goorah et al. 2009; Gorsevski et al. 2012). The criteria used to determine the importance of these characteristics are often contradictory. Many a times attempts for siting new landfills in the region have been rejected mostly by public opposition due to the lack of information given to the public, that creates the "not in my back yard" (NIMBY) syndrome for siting new landfills (Chiueh et al. 2008). The environmental regulations and increasing amounts of waste production further complicate the process with critical factors, which mechanically mask unsuitable areas, leaving very less options to be assessed. With such conflicting criteria, it is often impossible to find the 'optimal' landfill site. Thus, the selection of the suitable landfill site turns out to be a complex multi-criteria assessment and decision-making problem. Cheng et al. (2002) addressed the need for using multi-criteria decision making (MCDM) methodologies in solid waste management systems because these systems can have complex and conflicting impacts on different stakeholders.

Due to uncertainty and impreciseness of available information, apart from the ambiguity of human preferences, it is difficult to get accurate numerical values for the evaluation criteria. Therefore, most of the selection factors cannot be given correctly; this may hamper the evaluation process for decision-makers. The varying and conflicting nature of the criteria makes landfill site selection a critical process. The conventional methods are inadequate for dealing with the uncertainty involved in the process. To overcome this difficulty, fuzzy multi-criteria decisionmaking methods are proposed in this paper. Also, there are dependencies among the evaluation criteria that have to be analysed.

In the current study, an integrated fuzzy Delphi-fuzzyAHP-DEMATEL methodology has been used for identification and evaluation of an optimal landfill site selection criteria for MSW disposal, prioritizing them and finally studying the inter-relationship between these criteria. Fuzzy Delphi Method (FDM) is used to obtain the critical factors for selection of landfill sites. Next, the decisionmaker opinions on the relative importance of the selection criteria are determined by a fuzzy-Analytic Hierarchy Process (Fuzzy-AHP) procedure. However, fuzzy-AHP cannot determine the dependence and feedback among dimensions/criteria. In order to overcome this problem we use the Decision-making Trial and Evaluation Laboratory (DEMATEL) technique to build the casual relationship diagram. Thus, DEMATEL is applied to deal with the importance and causal relationships among the criteria, and to recognize the influential criteria of landfill site selection process.

The structure of the paper is as follows: Sect. 1 of the paper introduces the landfill siting problem and accentuates the need of MCDM tools. In Sect. 2, a brief literature review of previous papers reporting the use of any kind of MCDM technique in a landfill location related problem has been presented. In Sect. 3, i.e., "Materials and methods", a short description of the underlying theories has been presented. Finally, the results from the analysis are discussed in Sect. 4 and conclusions are outlined in Sect. 5.

\section{Literature review}

The disposal facility siting problem in waste management has been studied by many researchers globally using MCDM techniques alone or in combination with other techniques. The models for problem-solving have evolved from the single-criterion, maximin models (maximizing the average or minimum distance between the source and the site) (Hale and Moberg 2003), to multi-criteria models which include conflicting criteria. Erkut and Neuman (1989) classified the problems of undesirable facility siting according to: number of facilities to be located, solution space (network, tree or general), feasible region (discrete, continuous, other), distance measure, distance constraints, weights, distance terms included (minimum distance to the solution set or sum of the distances to the solution set), interactions considered and objective (single objective or multi-objective). The authors concluded that, the problem of undesirable facility location selection is clearly a multiobjective decision problem. Thus, many authors have applied multiple objective techniques in the waste facility location analysis (Stowers and Palekar 1993; Yildirim 2012; Gbanie et al. 2013). Also, models have been widely used for locating waste landfill sites to minimise exposure to the public and sensitive ecosystem.

Erkut and Moran (1991) developed an analytic hierarchy process (AHP) based decision modeling procedure that can 
be used to locate obnoxious facilities such as waste disposal sites. They also, demonstrated the applicability of the procedure in an analysis of decisions to locate a landfill site for the City of Edmonton, Alberta, Canada. They considered various social, economic, and environmental factors. Frantzis (1993) developed a model using cost and environmental criteria for landfill site selection. Muttiah et al. (1996) took into account, the criteria of risk to humans and environment in selection of optimum landfill site using GIS and simulated annealing. Baban and Flannagan (1998) discussed the importance of two major difficulties for landfill selection: (1) public acceptance, which is driven by social and political considerations and economic incentives, and (2) engineering and technical protocols for planning and protection of the physical environment.

Chang and Wei (2000) modeled the use of optimal features that should be considered in the solid waste collection network and landfill location, using fuzzy multiobjective nonlinear integer programming. Mahler and de Lima (2003) proposed a value analysis and fuzzy logic based methodology for the selection of suitable landfill sites by assessing and ranking a predefined pool of objects based on environmental and economic criteria. Vasiloglou (2004) presented a decision making process for the potential location of landfill sites with wide community participation. They proposed a comprehensive set of criteria for the potential sites encompassing social, environmental, and economic dimensions. Chau (2005) considered only risk criteria (e.g., groundwater migration, targets at risk, waste composition) in the selection of new landfill site using expert system based artificial neural network.

Kontos et al. (2005) took into consideration four criteria (social, environmental, technical, and economic) and eleven sub-criteria for the delineation of potential landfill sites. Eiselt (2006) considered minimum transportation costs for selecting ideal MSW landfill sites using mixed integer linear programming (MILP). Simsek et al. (2006) presented a method considering ground water risk.i.e., the vulnerability of ground water to contamination. The study involved the use of a DUPIT Model (a modified form of DRASTIC Model). Their method took into consideration five factors, namely depth of ground water, upper layer lithology, permeability of unsaturated zone, impermeable layer thickness and topographic slope. Norese (2006) proposed the consideration of cost of waste transportation, population, necessity of new roads, impact on landscape, agricultural value, and natural habitat protection as some of the criteria in selection of new landfill sites. Similar to Norese (2006), Queiruga et al. (2008) considered economic (land, personnel and energy costs), infrastructural (facility access, proximity to inhabited areas) and legal objectives in the selection of landfill site. In India, Sumathi et al. (2008) used a multi-criteria evaluation decision and overlay analysis for landfill site selection taking into account four criteria (land use, hydro-geologic, air quality and constraint parameterization). Chang et al. (2008) and Wang et al. (2009) focused on environmental considerations to minimize potential health and contamination risks from nearby landfill sites, while an economics oriented approach was used to minimize construction, operation and maintenance costs. Sharifi et al. (2009) proposed a model for new landfill site selection, in which they considered five main factors namely, geology, hydrogeology, hydrology, climatology and ecosociology. Adamides et al. (2009) considered minimum transportation cost and minimum social resistance as a criteria for landfill site selection using MILP method.

Aragonés-Beltrán et al. (2010) in Spain used analytic network process (ANP) and AHP based model for siting of suitable locations for a landfill considering plant exploitation costs, environmental issues, legal requirements, and facilities and infrastructures as evaluation and selection factors. Geneletti (2010) applied the MCDM technique of simple additive weighting for siting landfill locations in Italy. Their approach used factors such as visibility, accessibility and dust pollution, land cover and land use, elevation, slope, geology, soil permeability, natural hazards, hydrology, forest inventory, ecological sensitivity and values, protected areas, road network, settlements and population. Xi et al. (2010) considered the criteria of minimum transportation plus expansion costs, and public acceptance for landfill site selection using MILP and fuzzy MCDM approach. Babalola and Busu (2011) attempted to determine a suitable landfill location through ANP taking into account health, cost, environmental, social, and economic criteria. Aydi et al. (2013) employed fuzzy AHP, ELimination and Choice Expressing REality (ELECTRE) and the weighted linear combination method with GIS for landfill site selection. The authors considered geological, hydrologic and hydrogeological, environmental, social, and economic criteria in their study. Eskandari et al. (2012), considered socio-cultural, economic, technical, geographical, and environmental criteria for selecting new landfill site employing simple additive weighting in combination with GIS. Gorsevski et al. (2012) considered two criteria (environmental and economic) for landfill site selection using integration of GIS, AHP and ordered weighted average (OWA) techniques. Yildirim (2012) considered social, economic, and environmental criteria for selecting landfill site using AHP. More recently, Makan et al. (2012) applied Preference Ranking Organization METHod for Enrichment of Evaluations (PROMETHEE) for suitable waste disposal site selection considering, social, economic, environmental, and technical criteria. AHP in combination with GIS was used by Alavi et al. (2013) for landfill site selection considering, environmental, socio- 
culture, and technical-economical factors. Gbanie et al. (2013) considered three major criteria geo-environmental, sociopolitical and economic factors for optimum landfill site selection using a multi-criteria GIS approach that blends two aggregation techniques: weighted linear combination and OWA. Eiselt and Marianov (2014) used MILP considering minimum cost and less pollution as a criteria for selecting landfill site.

Overall the earlier siting models for solid waste management primly focused on financial factors. Later, the awareness about the potential of pollution of waste disposal led to more restrictive environmental regulations for the siting, implementing and operating of waste facilities. Regardless of the techniques implemented, the main criteria cited by different authors are mainly: technical, economic, environmental, social, operations and management, natural factors (hydrogeological, geological and topographical criteria), and artificial factors (accessibility, infrastructure, urban centres, villages and land use). Political and sociological factors, on the other hand, are typically less considered in the quantitative assessment procedures but only during the final approval of a selected site. However, this approach has created many difficulties in the past and a lot of selected sites have received strong opposition from local population. Similarly, increased traffic load is another reason for public's opposition. A number of authors (Sumathi et al. 2008) has argued that landfill selection process should utilise relevant available data and planners should arrive at results accepted by all stakeholders in the selection process. After a thorough revision of the related literature no references related to the systematic and scientific identification of landfill site selection criteria, evaluation, prioritization and studying the inter-relationship between the criteria have been found.

An overview of the above-mentioned studies amply accentuates that the MCDM methods such as AHP and fuzzy model have been introduced as applied and current models during the recent years and tangible results of the calculations of these models has been revealed. However, some of these studies did not take into account the supply of imprecise data and the uncertainty involved in the decision making process, apart from lacking logical interpretation.

\section{Materials and methods}

A sound landfill site selection process requires consideration of extensive criteria and evaluation steps to identify the best available disposal locations and to eliminate subsequent issues. In this paper, the problem of MSW disposal site selection is studied on three levels: identification of relevant selection criteria, their evaluation by assigning weights to the decision criteria and to calculate their importance degree followed by evaluating the inter-relationship between them. The proposed model for the identification of a potential landfill site has been made possible through the integration of environmental, technical, sociopolitical and economic factors.

\section{Fuzzy Delphi method}

The purpose is to find a comprehensive, operational, nonredundant and minimal set of decision making criteria that would represent the various objectives.

The FDM was proposed by Ishikawa et al. (1993), having been derived from the fuzzy set theory and the traditional Delphi technique. The FDM applied to group decision making can solve the fuzziness of common understanding of expert opinions (Noorderhaben 1995). The current study used FDM for the screening of criteria for the evaluation and landfill selection process. The triangular fuzzy numbers and functions were used to solve the group decision making problem.

\section{Screening of criteria by FDM}

Twenty-one (21) criteria for MSW landfill site selection were identified based on relevant literature review (Hokkanen and Salminen 1997), experts opinion and the on the knowledge and the experience of the decision makers.

The FDM procedure used is as follows:

1. Collection of the expert group opinions: An FDM interview table was set up for the 21 criteria as the key evaluation factors. After this, the interviews with experts from the academia, consultancies and municipal authorities were conducted. The evaluation score was calculated depending upon the importance given to each alternate criterion by individual experts using the linguistic variables in questionnaires.

2. Setting up of the triangular fuzzy numbers: The opinions of experts in FDM questionnaires were converted to triangular fuzzy numbers. The evaluation value of the triangular fuzzy number of each alternate criterion given by the experts was calculated, and the significant triangular fuzzy number of the alternate factor was determined. The fuzzy numbers used for this purpose and their definitions are shown in Table 1. The fuzzy scale used for the evaluation is shown in Fig. 1. Next, for capturing the common understanding of expert group decisions, and to reduce the ambiguity the geometric mean model of mean general model proposed by Klir and Yuan (1995) was adopted. The computing formula is illustrated as follows:

If the evaluation value of the significance of No. j 
Table 1 Definitions of Fuzzy number

\begin{tabular}{lll}
\hline \multicolumn{2}{l}{ Fuzzy numbers } & Definition \\
\hline$\tilde{1}$ & $(1,1,1)$ & Equally important \\
$\tilde{2}$ & $(1,2,3)$ & Equally to moderate important \\
$\tilde{3}$ & $(2,3,4)$ & Moderately more important \\
$\tilde{4}$ & $(3,4,5)$ & Moderately and strongly important \\
$\tilde{5}$ & $(4,5,6)$ & More strongly important \\
$\tilde{6}$ & $(5,6,7)$ & Strongly and very strongly important \\
$\tilde{7}$ & $(6,7,8)$ & More very strongly important \\
$\tilde{8}$ & $(7,8,9)$ & Very strongly to extremely important \\
$\tilde{9}$ & $(8,9,9)$ & Extremely more important \\
\hline
\end{tabular}

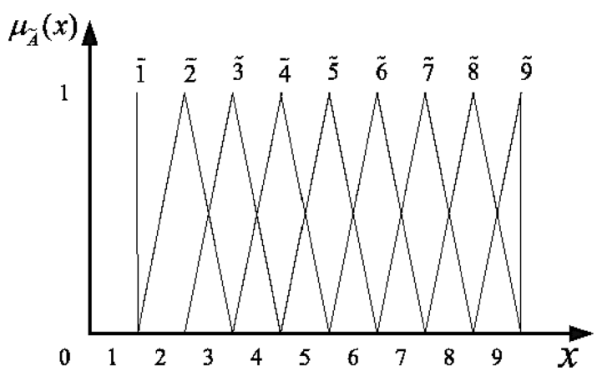

Fig. 1 The Fuzzy numbers scale

element given by No. $\mathrm{i}$ expert of $\mathrm{n}$ experts is $\tilde{w} i j=($ aij; bij; cij), $\mathrm{i}=1,2 ; \ldots ; \mathrm{n} ; \mathrm{j}=1,2 ; \ldots, \mathrm{m}$. Then the fuzzy weighing $\tilde{w} \mathrm{j}$ of No. $\mathrm{j}$ element is given by, $\tilde{w} \mathrm{j}=(\mathrm{aj} ; \mathrm{bj} ; \mathrm{cj}) ; \mathrm{j}=1,2 ; \ldots, \mathrm{m}$.

Among which

$a=\operatorname{Max}_{i} a i j, \mathrm{bj}=1 / n \sum_{(n-1)}^{n} \mathrm{bij}, \mathrm{c}=\operatorname{Max}_{i} C i j$

3. Defuzzification of fuzzy values: The simple centre of gravity method was used for defuzzification of the fuzzy values. Thus, the defuzzified value of the fuzzy weight $\tilde{w} j$ of each alternate element to definite value $\mathrm{Sj}$ was obtained as follows:

$\mathrm{Sj}=\mathrm{aj}+\mathrm{bj}+\mathrm{cj} / 3$ where $\mathrm{j}=1,2 ; \ldots, \mathrm{m}$

If $\mathrm{Sj} \geq \alpha$, then No. $\mathrm{j}$ factor is the evaluation index. If $\mathrm{Sj}<\alpha$, then delete No. $\mathrm{j}$ factor.

4. Screening evaluation factors: Finally, proper and relevant criteria were screened out from numerous factors by setting the threshold $\alpha$. The general FDM diagram with threshold $\alpha$ is shown in Fig. 2. The approach used for screening is as follows:

Elements with alpha $(\alpha)$ value less than 8 were deleted, thus retaining only 12 initial criteria. The important evaluation criteria, after screening and output of FDM

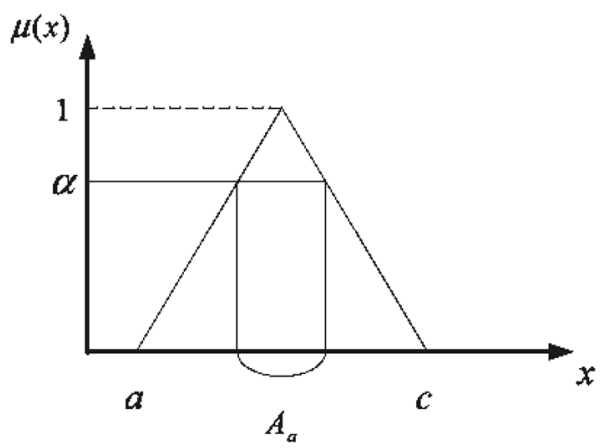

Fig. 2 Fuzzy Delphi method diagram

is shown in Table 2. Thus, more objective evaluation criteria could be obtained through statistical analysis. FDM formed by including the fuzzy theory was found to be more economical and less time consuming than the traditional Delphi method.

\section{Description of all selection criteria}

The 12 important evaluation criteria after screening with their operational definitions are described below. The developed criteria encompass environmental conditions, accessibility, geological and hydrogeological conditions, ecological and societal effects.

1. Public acceptance (PA) The location identified should be accepted socially.

2. Hydrology $(H Y)$ Pollution of surface and ground water resources by leachate is a prime concern.

3. Climate $(C L)$ Wind and rain are common climatic factors influencing site selection, especially in the coastal areas. If the site is exposed to strong winds, coastal disasters are a distinct possibility, and adequate coastal protection is a must. Also, for high rainfall areas, to minimise leachate production, effective storm water diversion is essential.

4. Soil and topography (SAT) A suitable site will have a sufficient grade to provide drainage of surface runoff and adequate level areas to enable excavation of trenches and associated earthworks and the construction of service facilities avoiding potential ground water problems, soil erosion risk, access, and providing site visibility and protection from prevailing winds. Sites with slopes exceeding 1:5 are generally not suitable because of the soil erosion risk.

5. Fracture and faults $(F N F)$ Faulted zone locations should be avoided if possible.

6. Adjacent land use (ALU) Existing and possible future developments adjacent to the site should be 
Table 2 Fuzzy Delphi method results

\begin{tabular}{llllllll}
\hline Criteria & A & B & $\gamma$ & U & M & $\begin{array}{l}\text { L } \\
\text { Best non-fuzzy } \\
\text { performance }\end{array}$ \\
\hline Public acceptance (PA) & 7.666667 & 8.666667 & 9 & 9 & 8.666667 & 7.666667 & 9.333333 \\
Hydrology (HY) & 7.333333 & 8.333333 & 9 & 9 & 8.333333 & 7.333333 & 9.333333 \\
Climate (CL) & 7.333333 & 8.333333 & 8.666667 & 8.666667 & 8.333333 & 7.333333 & 9 \\
Soil and topography (SAT) & 7.333333 & 8.333333 & 9 & 9 & 8.333333 & 7.333333 & 9.333333 \\
Fracture and faults (FNF) & 7 & 8 & 8.666667 & 8.666667 & 8 & 7 & 9 \\
Adjacent land use (ALU) & 6 & 7 & 8 & 8 & 7 & 6 & 8.333333 \\
Sensitive areas (SA) & 6.666667 & 7.666667 & 8.666667 & 8.666667 & 7.666667 & 6.666667 & 9 \\
Habitat, flora and fauna (HAF) & 7 & 7.666667 & 8.666667 & 8.666667 & 7.666667 & 7 & 8.888889 \\
Inter-municipality (INM) & 7.333333 & 8.333333 & 8.666667 & 8.666667 & 8.333333 & 7.333333 & 9 \\
Site capacity (SC) & 7.333333 & 8.333333 & 9 & 9 & 8.333333 & 7.333333 \\
Cost (COS) & 7.666667 & 8.666667 & 9 & 9 & 8.666667 & 7.666667 & 9.333333 \\
Road network/access (RNA) & 6.666667 & 7.666667 & 8.333333 & 8.333333 & 7.666667 & 6.666667 & 8.666667 \\
\hline
\end{tabular}

considered. Locations with higher potential for nature conservation, agriculture and residential development should not be considered, e.g., wetlands etc.

7. Sensitive areas (SA) Presence of airports, nuclear sites, electrical supply lines, oil ducts, petrochemical industries etc. in the nearby areas is not desirable.

8. Habitat, flora and fauna (HAF) Sites having natural flora and fauna and habitation are unsuitable as the landfill can cause major disruption to them. Control of vermin populations, bird, rodents, and other animal pests is an important factor in maintaining both public health and environmental stability.

9. Inter-municipality (INM) More than one municipality may use the facility, sharing building and maintenance costs.

10. Site capacity (SC) Identified sites should have enough capacity.

11. Cost (COS) Each location has its own cost value.

12. Road network/access (RNA) Direct access to the site so that waste is not dumped before getting to the landfill, and to minimize waste spillage, traffic congestion and fuel usage of vehicles.

\section{Fuzzy-analytic hierarchy process (F-AHP)}

After screening criteria, a general consensus among experts was achieved, which was used to establish a hierarchical structure and calculating the weights and importance degree of each evaluation criterion.

In this study, the framework of the feasible regions of relative weights was adopted. Firstly, allowing the feasible region to include tolerance deviations of the fuzzy ratios, we defined fuzzy consistency as the existence of relative weights within the region. Secondly, we devised a maximum/minimum set ranking method to derive a crisp ranking from the global fuzzy weights. There are two main characteristics of fuzzy systems that allow them to give better performance for specific applications: (1) fuzzy systems are suitable for uncertain or approximate reasoning, especially for the system with a mathematical model that is difficult to derive; and (2) fuzzy logic allows decision making with estimated values under incomplete, imprecise or uncertain information. Hence, fuzzy logic was combined and used along with AHP, and resulted in a fuzzy-AHP methodology for reviewing and weighting the landfill site selection criteria.

The following steps of fuzzy-AHP proposed by Chang (1996) were utilized for selecting and ranking the criteria in the multi-period phase. According to the method of Chang's extent analysis, each object is taken and extent analysis for each goal is performed respectively. Therefore, $m$ extent analysis values for each object can be obtained, with the following signs:

$M_{g^{i}}^{1}, M_{g^{i}}^{2}, \ldots, M_{g^{i}}^{m}, \quad i=1,2, \ldots, n$.

where $M_{g^{i}}^{j}(j=1,2, \ldots, m$.$) all are TFNs (triangular fuzzy$ numbers).

The steps of Chang's extent analysis (Chang 1996) are as follows:

i. The value of fuzzy synthetic extent with respect to the $i$ th object is defined as

$S_{i}=\sum_{j=1}^{m} M_{g^{i}}^{j} \otimes\left[\sum_{i=1}^{n} \sum_{j=1}^{m} M_{g^{i}}^{j}\right]^{-1}$

To obtain $\sum_{j=1}^{m} M_{g^{i}}^{j}$, the fuzzy addition operation of $\mathrm{m}$ extent analysis values for a particular matrix is performed as 
$\sum_{j=1}^{m} M_{g^{i}}^{j}=\left(\sum_{j=1}^{m} l_{j}, \sum_{j=1}^{m} m_{j}, \sum_{j=1}^{m} u_{j}\right)$

and to obtain $\left[\sum_{i=1}^{n} \sum_{j=1}^{m} M_{g^{i}}^{j}\right]$, the fuzzy addition operation of $M_{g^{i}}^{j}(j=1,2, \ldots, m$. $)$ values is performed such that,

$\left[\sum_{i=1}^{n} \sum_{j=1}^{m} M_{g^{i}}^{j}\right]=\left(\sum_{i=1}^{n} l_{i}, \sum_{i=1}^{n} m_{i}, \sum_{i=1}^{n} u_{i}\right)$

and $\left[\sum_{i=1}^{n} \sum_{j=1}^{m} M_{g^{i}}^{j}\right]^{-1}$ can be calculated by the inverse of Eq. (3), as follows:

$\left[\sum_{i=1}^{n} \sum_{j=1}^{m} M_{g^{i}}^{j}\right]^{-1}=\left(\frac{1}{\sum_{i=1}^{n} u_{i}}, \frac{1}{\sum_{i=1}^{n} m_{i}}, \frac{1}{\sum_{i=1}^{n} l_{i}}\right)$

As $M_{1}=\left(l_{1}, m_{1}, u_{1}\right)$ and $M_{2}=\left(l_{2}, m_{2}, u_{2}\right)$ are two triangular fuzzy numbers, the degree of possibility of $M_{2}=\left(l_{2}, m_{2}, u_{2}\right) \geq M_{1}=\left(l_{1}, m_{1}, u_{1}\right)$ is defined as

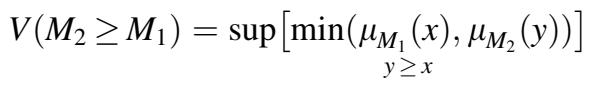

ii. and can be equally expressed as follows:

$$
\begin{aligned}
& V\left(M_{2} \geq M_{1}\right)=h g t\left(M_{1} \cap M_{2}\right)=\mu_{M_{2}}(d) \\
& =\left\{\begin{array}{cc}
1 & \text { if } m_{2} \geq m_{1} \\
0 & \text { if } l_{1} \geq u_{2} \\
\frac{\left(l_{1}-u_{2}\right)}{\left(m_{2}-u_{2}\right)-\left(m_{1}-l_{1}\right)} & \text { otherwise }
\end{array}\right.
\end{aligned}
$$

Fig. 3 (Chang 1996) shown below illustrates Eq. (6) where $d$ is the ordinate of the highest intersection point $\mathrm{D}$ between $\mu_{M_{1}}$ and $\mu_{M_{2}}$. To compare $M_{1}=$ $\left(l_{1}, m_{1}, u_{1}\right)$ and $M_{2}=\left(l_{2}, m_{2}, u_{2}\right)$, we need both the values of $V\left(M_{1} \geq M_{2}\right)$ and $V\left(M_{2} \geq M_{1}\right)$.

iii. The degree possibility for a convex fuzzy number to be greater than $k$ convex fuzzy $M_{i}(i=1,2, \ldots, k)$ numbers can be defined by

$$
\begin{aligned}
& V\left(M \geq M_{1}, M_{2}, \ldots, M_{k}\right)=V\left[\left(M \geq M_{1}\right)\right. \\
& \left.\quad \text { and }\left(M \geq M_{2}\right) \text { and } \ldots \text { and }\left(M \geq M_{k}\right)\right] \\
& =\min V\left(M \geq M_{i}\right), i=1,2, \ldots, k
\end{aligned}
$$

Assume that

$d\left(A_{i}\right)=\min V\left(S_{i} \geq S_{k}\right) \quad$ for $k=1,2, \ldots, n ; \quad k \neq i$.

Then the weight vector is given by

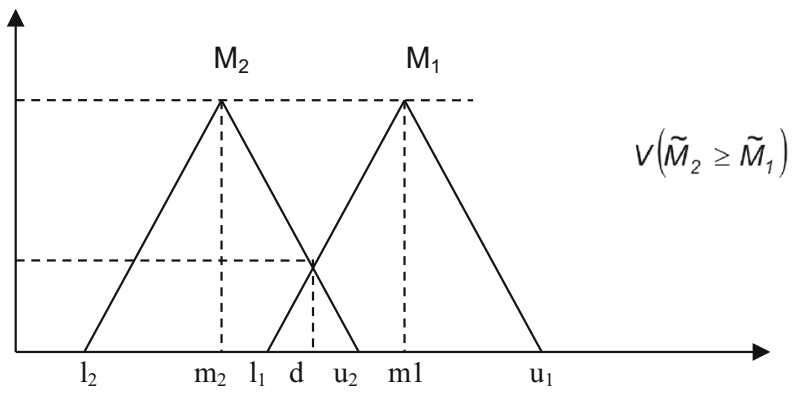

Fig. 3 Intersection between M1 and M2 (Kahraman et al. 2004)

$$
W^{\prime}=\left(d^{\prime}\left(A_{1}\right), d^{\prime}\left(A_{2}\right), \ldots, d^{\prime}\left(A_{n}\right)\right)^{T}
$$

where $A_{i}(i=1,2, \ldots, n)$ are the $n$ elements.

iv. After normalisation, the normalised weight vectors are

$W=\left(d\left(A_{1}\right), d\left(A_{2}\right), \ldots, d\left(A_{n}\right)\right)^{T}$

where $W$ is a non-fuzzy number.

On the basis of the hierarchical framework of the siting indexes, the F-AHP questionnaire using FTN (Fuzzy triangular numbers) was distributed among the experts for soliciting their professional opinions. The relative importance (fuzzy weight) of each criteria analyzed by F-AHP is listed in Table 3.

\section{Application of Decision-making Trial and Evaluation Laboratory (DEMATEL)}

DEMATEL was developed by Geneva Research Centre of the Battelle Memorial Institute (Gabus and Fontela 1973; Fontela and Gabus 1976). It is a comprehensive method for constructing and examining a structural model of the causal relationships among the complex and multiple criteria (Lin and Lin 2008). DEMATEL has the ability not only to demonstrate directed relationships of sub-systems, but also to clarify the degree of interactions between sub-systems (Wu 2012). DEMATEL aims to obtain direct and indirect causation and the strength of influence across quality features by applying matrix computation to complex systems, and comparing the interrelations among the quality features (Lee et al. 2013). Thus, it provides an effective way to handle the inner dependences within a set of criteria.

The procedure of DEMATEL is as follows:

Step 1 Calculation of the direct-influence matrix: The first step in DEMATEL is to calculate direct influence matrix with the help of expert views. Mutual relationship among the attributes is being evaluated using a scale from 1 to 5 ( 1 for no influence and 5 for very high influence. Each expert is asked: "To what degree does factor $\mathrm{i}$ 
Table 3 Fuzzy weights of performance evaluation index by F-AHP

\begin{tabular}{lllllcc}
\hline Criteria & $\alpha$ & $\beta$ & $\gamma$ & \multicolumn{2}{l}{ Best non-fuzzy performance } \\
\cline { 4 - 6 } & & & & \multicolumn{2}{l}{$[(\mathrm{U}-\mathrm{L})+(\mathrm{M}-\mathrm{L})] / 3+\mathrm{L}$} & 10.30381074 \\
\hline Hydrology (HY) & 0.078273034 & 0.101978808 & 0.12886248 & 0.103038107 & 2 \\
Sensitive areas (SA) & 0.073189279 & 0.090645393 & 0.108895491 & 0.090910054 & 9.091005435 \\
Soil and topography (SAT) & 0.087195632 & 0.094615897 & 0.100205011 & 0.094005514 & 9.400551354 & 4 \\
Habitat and flora \& fauna (HAF) & 0.088215792 & 0.0956239 & 0.099016338 & 0.094285343 & 9.428534335 \\
Climate (CL) & 0.093057903 & 0.104275293 & 0.112047935 & 0.103127043 & 10.31270435 \\
Fracture and faults (FNF) & 0.070969262 & 0.07419064 & 0.078402389 & 0.074520764 & 7.4520764 \\
Public acceptance (PA) & 0.082237151 & 0.07526837 & 0.067493175 & 0.074999565 & 7.499956538 \\
Adjacent land use (ALU) & 0.073684553 & 0.070555984 & 0.067542988 & 0.070594508 & 7.059450843 & 1 \\
Intra-municipality (INM) & 0.080829767 & 0.073455331 & 0.063869715 & 0.072718271 & 7.271827108 & 10 \\
Cost of site (COS) & 0.08143124 & 0.071331433 & 0.060944339 & 0.071235671 & 7.123567057 & 11 \\
Road network/access (RNA) & 0.094282332 & 0.073268209 & 0.057220789 & 0.074923777 & 7.492377651 & 8 \\
Site capacity (SC) & 0.096634053 & 0.074790742 & 0.05549935 & 0.075641382 & 7.564138189 & 6 \\
\hline
\end{tabular}

affect factor $\mathrm{j}$ ?" The initial direct-relation matrix $\mathrm{D}=[\mathrm{dij}]_{\mathrm{nxn}}$ is obtained through pair wise comparisons in terms of influences and directions between criteria, in which $\mathrm{n}$ denotes the number of criteria (Shen et al. 2012). If there are $n$ variables that impact the system, a direct influence matrix will look like,

$$
\mathrm{D}=\begin{array}{cccc}
0 & \mathrm{~d} 12 & \mathrm{~d} 12 & \mathrm{~d} 1 \mathrm{n} \\
\mathrm{d} 21 & 0 & \mathrm{~d} 23 & \mathrm{~d} 2 \mathrm{n} \\
\mathrm{d} 31 & \mathrm{~d} 32 & 0 & \mathrm{~d} 3 \mathrm{n} \\
\mathrm{dn} 1 & \mathrm{dn} 2 & \mathrm{dn} 3 & 0
\end{array}
$$

Here authors have used 12 criteria of landfill site evaluation and on basis of scores obtained from variouslexperts; direct-influence matrix has been obtained.

Step 2 Normalize the direct-influence matrix: Once the direct-influence matrix has been obtained, it can be normalized by using Eqs. (12) and (13) to get the initial normalized direct influence matrix ' $N$ '.

$\mathrm{m}=\min \left[\frac{1}{\sum_{\mathrm{j}=1}^{\mathrm{n}} \mathrm{dij}}, \frac{1}{\sum_{\mathrm{i}=1}^{\mathrm{n}} \mathrm{dij}}\right]$

$\mathrm{N}=\mathrm{D} / \mathrm{m}$

Step 3 Obtain total Influence Matrix: Once the normalized direct-relation matrix $\mathrm{X}$ is obtained, the total relation matrix $\mathrm{T}$ can be acquired by using Eq. (14)

$$
\begin{aligned}
& \mathrm{T}=\mathrm{N}+\mathrm{N}^{1}+\mathrm{N}^{2}+\mathrm{N}^{3}+\mathrm{N}^{4}+\mathrm{N}^{q} \\
& \mathrm{~T}=\mathrm{N}\left(I+\mathrm{N}+\mathrm{N}^{1}+\mathrm{N}^{2}+\mathrm{N}^{3}+\mathrm{N}^{4}+\mathrm{N}^{q-1}\right) \\
& \left.\quad\left[(I-\mathrm{N})(I-\mathrm{N})^{-1}\right\}\right] \\
& =\mathrm{N}\left(I-\mathrm{N}^{q}\right)(I-\mathrm{N})^{-1} \\
& \text { Then } \quad \mathrm{T}=\mathrm{N}(\mathrm{N}-1)^{-1}
\end{aligned}
$$

$$
\text { where I = Identity Matrix (Table 4) }
$$

The sum of rows is denoted by $\mathrm{d}$ and of columns is denoted by $\mathrm{R}$ through Eqs. $(15,16,17)$. Addition of $\mathrm{d}$ and $\mathrm{R}$ reveals the relative importance of each criterion. And the subtraction of $\mathrm{d}$ and $\mathrm{R}$ divides the criteria into two groups: cause group and effect group. When $(d-R)$ is positive, that particular criteria dimension belongs to the cause group and when the $(\mathrm{d}-\mathrm{R})$ is negative, that criteria belongs to the effect group. Therefore, the causal diagram can be obtained by mapping the dataset of the $(d+R, d-R)$.

$\mathrm{T}=\left[\mathrm{t}_{\mathrm{ij}}\right]_{\mathrm{nxn}}, \mathrm{i}, \mathrm{j}=1,2,3,4, \ldots \ldots, \mathrm{n}$

$\mathrm{d}=\left[\sum_{(\mathrm{j}=1)}^{\mathrm{n}} \mathrm{tij}\right]=[\mathrm{ti}] \mathrm{nx} 1$

$\mathrm{R}=\left[\sum_{(\mathrm{i}=1)}^{\mathrm{n}} \mathrm{tij}\right]=[\mathrm{tj}] 1 \mathrm{xn}$

where $\mathrm{d}$ and $\mathrm{R}$, respectively denote the sum of rows and the sum of columns from total relation matrix $\mathrm{T}=[\mathrm{tij}]_{\mathrm{nxn}}$. 
Table 4 Total relation matrix, $\mathrm{T}=\mathrm{x}(\mathrm{I}-\mathrm{X})$

\begin{tabular}{|c|c|c|c|c|c|c|c|}
\hline & HY & SA & SAT & HAF & $\mathrm{CL}$ & FNF & PA \\
\hline HY & 0.988885866 & 1.129048353 & 0.916300595 & 1.107786651 & 1.06515326 & 1.059819239 & 0.998111806 \\
\hline SA & 1.32691861 & 1.343836971 & 1.106440569 & 1.3839737 & 1.342766342 & 1.336503842 & 1.251270355 \\
\hline SAT & 1.270538358 & 1.383817168 & 1.000188315 & 1.272599258 & 1.261287094 & 1.249744637 & 1.175728798 \\
\hline HAF & 1.330325575 & 1.442445642 & 1.144210546 & 1.292600332 & 1.352802491 & 1.346320492 & 1.260591666 \\
\hline $\mathrm{CL}$ & 1.27232533 & 1.379294687 & 1.073442469 & 1.327201668 & 1.207661227 & 1.273475786 & 1.213554345 \\
\hline FNF & 1.240224685 & 1.337622451 & 1.046378237 & 1.286956302 & 1.2694675 & 1.169146305 & 1.168386854 \\
\hline PA & 1.323516401 & 1.441848107 & 1.115888813 & 1.380071148 & 1.36050542 & 1.332043512 & 1.175005243 \\
\hline ALU & 1.219248313 & 1.307437343 & 1.020364957 & 1.242765164 & 1.21148389 & 1.227533333 & 1.170316023 \\
\hline INM & 1.339581413 & 1.450444144 & 1.110279273 & 1.367336884 & 1.340011977 & 1.334728102 & 1.241809416 \\
\hline COS & 1.211911004 & 1.3220573 & 1.035567037 & 1.250090716 & 1.226010163 & 1.227556752 & 1.156237111 \\
\hline RNA & 1.168840556 & 1.291443989 & 0.995738825 & 1.205478575 & 1.196566031 & 1.198782773 & 1.114641323 \\
\hline $\mathrm{SC}$ & 1.296770656 & 1.415147428 & 1.106099881 & 1.36687124 & 1.333976805 & 1.335336445 & 1.228655697 \\
\hline \multirow[t]{2}{*}{$\mathrm{Ri}$} & 14.98908677 & 16.24444358 & 12.67089952 & 15.48373164 & 15.1676922 & 15.09099122 & 14.15430864 \\
\hline & ALU & INM & \multicolumn{2}{|l|}{ COS } & RNA & SC & Di \\
\hline HY & 1.044518655 & \multicolumn{2}{|c|}{1.087972096} & 1.127636224 & 1.064187174 & 1.098068356 & 12.6874883 \\
\hline SA & 1.316978566 & \multicolumn{2}{|c|}{1.37319841} & 1.403190393 & 1.34265294 & 1.390296798 & 15.9180275 \\
\hline SAT & 1.283923203 & \multicolumn{2}{|c|}{1.314110004} & 1.365658103 & 1.2929319 & 1.32367278 & 15.1941996 \\
\hline HAF & 1.328276574 & \multicolumn{2}{|c|}{1.384223926} & 1.415041962 & 1.353679724 & 1.40127547 & 16.0517944 \\
\hline CL & 1.262639297 & \multicolumn{2}{|c|}{1.322908521} & 1.366462913 & 1.279453751 & 1.32620188 & 15.3046219 \\
\hline FNF & 1.215982468 & \multicolumn{2}{|c|}{1.289783009} & 1.318831686 & 1.261468959 & 1.292586644 & 14.8968351 \\
\hline PA & 1.320750607 & \multicolumn{2}{|c|}{1.391270642} & 1.392263476 & 1.345856462 & 1.379494061 & 15.9585139 \\
\hline ALU & 1.13780404 & \multicolumn{2}{|c|}{1.283179471} & 1.295298471 & 1.240764672 & 1.270297118 & 14.6264928 \\
\hline INM & 1.337172859 & \multicolumn{2}{|c|}{1.299629408} & 1.409444322 & 1.362851626 & 1.395698641 & 15.9889881 \\
\hline $\cos$ & 1.217345613 & \multicolumn{2}{|c|}{1.254092527} & 1.21699814 & 1.24057774 & 1.270628657 & 14.6290728 \\
\hline RNA & 1.18898362 & \multicolumn{2}{|c|}{1.252877756} & 1.287506571 & 1.132314934 & 1.226287101 & 14.2594621 \\
\hline $\mathrm{SC}$ & 1.309417021 & \multicolumn{2}{|c|}{1.379339381} & 1.402460055 & 1.349388772 & 1.287904216 & 15.8113676 \\
\hline $\mathrm{Ri}$ & 14.96379252 & \multicolumn{2}{|c|}{15.63258515} & 6.00079232 & 15.26612865 & 15.66241172 & \\
\hline
\end{tabular}

\section{Results and discussion}

The fuzzy AHP technique was applied to determine the importance degree of each selection criteria and determine the ranking of the criteria. According to the result of fuzzyAHP as shown in Table 3, the criteria of climate received highest weight value (10.31270435). This is particularly important as, the climate of the region can play major role in considering a potential site for waste disposal, climate also, affects other factors of the potential landfill site. Regions exposed to strong winds or heavy rainfall needs special attention when considering a site for disposing solid waste.

Followed by climate, hydrology (10.30381074), habitat and flora \& fauna (9.428534335), soil and topography (9.400551354) gained second, third, and fourth rank respectively. The hydrological characteristics of potential site are important, as poor hydrological conditions can cause contamination of surface water bodies, as well as contamination of ground water by landfill leachate, posing threat to human and environmental health. Further, the presence of natural flora and fauna and habitation near to the potential site makes the site unsuitable, as the landfill can cause major disruption to them, and affect ecological balance. Soil and topography of the potential landfill site will have impact, as a suitable site should have a sufficient grade to provide drainage of surface runoff and adequate level areas to enable excavation of trenches and associated earthworks and the construction of service facilities avoiding potential ground water problems, soil erosion risk, access, and providing site visibility and protection from prevailing winds.

The other criteria in the decreasing order of their rank are, sensitive areas, site capacity, public acceptance, road network/access, fracture and faults, intra-municipality, site cost and adjacent land use. 


\section{DEMATEL causal diagram}

The selection criteria are inter-dependent. The inter-relationships among the dimensions and criteria are obtained using DEMATEL. Initially the direct-influence matrix D and the total-influence matrix $\mathrm{T}$ were obtained. The influence of the factors of interest is shown in Table 4. Based on the above analysis; a comprehensive impact relation map has been generated, as illustrated in Fig. 4. The values $\mathrm{di}+\mathrm{Ri}$, and $\mathrm{di}-\mathrm{Ri}$ represent the relationships among the criteria. The di value reflects the influence on other dimensions, while the Ri factor reflects the influence from other dimensions. $\mathrm{di}+\mathrm{Ri}$ represents the degree of the relationship between dimensions, while di - Ri represents the degree of the effect. The horizontal axis on the DEMATEL impact relation map is $\mathrm{di}+\mathrm{Ri}$, and the vertical axis is di - Ri.

As inferred from the above, criteria having the higher value of $(\mathrm{d}+\mathrm{Ri})$ are among those which according to the experts participating in this study have the highest degree of relationship with other landfill selection criteria. From the initial DEMATEL analysis, the four criteria with the highest di + Ri values are:

1. Sensitive areas (SA)

2. Intra-Municipality (INM)

3. Habitat, flora and fauna (HAF)

4. Site capacity (SC)

The presence of sensitive areas such as, airports, nuclear sites, electrical supply lines, oil ducts, petrochemical industries, ecological important area etc. in the nearby areas is not desirable, as they pose serious threat to the environment and human life. The presence of such areas can complicate the conditions in case of some emergency. The sharing of landfill site is an excellent idea, but acceptance of it is critical in real-time. In most of the

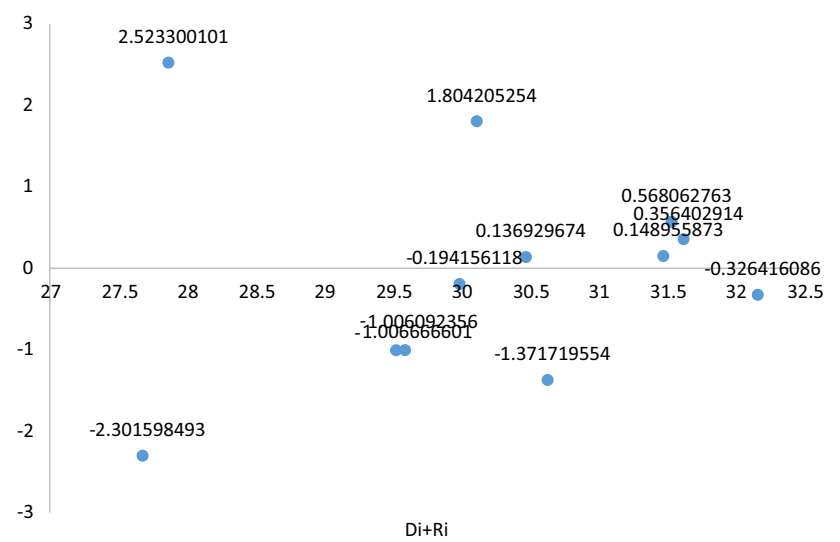

Fig. 4 DEMATEL plot indicating the relative level of different criteria dimensions densely populated cities, where there is scarcity of land, this option can be beneficial. Additionally, the identified potential site should have enough capacity to serve and sustain for long duration of time.

Row sum (Di) tells about the influence of particular criteria over other criteria dimensions. Higher the row sum means higher the influence. Table 5 below shows the degree of influence of each criteria over other criteria.

\section{Result summary- DEMATEL}

\begin{tabular}{|c|c|}
\hline $\begin{array}{l}\text { Criteria with highest } \\
\text { degree of relationship }\end{array}$ & Sensitive area \\
\hline $\begin{array}{l}\text { Criteria with highest } \\
\text { degree of effect }\end{array}$ & Soil and topography \\
\hline Cause group criteria & $\begin{array}{l}\text { Soil and topography, habitat and flora \& } \\
\text { fauna, climate, public acceptance, } \\
\text { intra-municipality, site capacity }\end{array}$ \\
\hline Effect group criteria & $\begin{array}{l}\text { Hydrology, sensitive areas, fracture and } \\
\text { faults, adjacent land use, cost of site, } \\
\text { road network/access }\end{array}$ \\
\hline $\begin{array}{l}\text { Dimension with maximum } \\
\text { influence (giver) }\end{array}$ & Intra-municipality \\
\hline $\begin{array}{l}\text { Dimension with maximum } \\
\text { influence (receiver) }\end{array}$ & Sensitive area \\
\hline
\end{tabular}

From the result obtained it can be said that habitat and flora $\&$ fauna and intra-municipality are those criteria which have the maximum influence on other criteria identified in this research. Also the highest column sum (Ri) indicates the criteria which receive the highest effect among other flexibilities. As seen from the table, sensitive areas and cost criteria receives the highest effect from other dimensions identified in this research.

The value of $(D-R)$ segregated the flexibilities into two groups: cause group and effect group. From the result obtained it can be said that these landfill site selection criteria requires a high level of focus on the cause group (Soil and topography, Habitat and flora \& fauna, Climate, Public acceptance, Intra-municipality, and Site capacity) rather than the effect group (Hydrology, Sensitive areas, Fracture and faults, Adjacent land use, Cost of site, and Road network/access); the cause group factors are difficult to move, while the effect group factors are easily moved (Hori and Shimizu 1999). Further, through above causal diagram (Fig. 4) it can be inferred that among these twelve dimensions Sensitive area (SA) is the most important (highest degree of relationship) factor by the highest $(\mathrm{D}+\mathrm{R})$ priority of 32.162. And, soil and topography (SAT) is the dimension with highest degree of effect by the highest $(\mathrm{D}-\mathrm{R})$ priority of 2.523 . 
Table 5 Degree of influence of landfill selection criteria

\begin{tabular}{llllrl}
\hline & Di & Ri & Di + Ri & \multicolumn{1}{l}{ Di - Ri } & Relationship \\
\hline HY & 12.6874883 & 14.98908677 & 27.67657504 & -2.301598493 & Effect \\
SA & 15.9180275 & 16.24444358 & 32.16247108 & -0.326416086 & Effect \\
SAT & 15.1941996 & 12.67089952 & 27.86509914 & 2.523300101 & Cause \\
HAF & 16.0517944 & 15.48373164 & 31.53552604 & 0.568062763 & Cause \\
CL & 15.3046219 & 15.1676922 & 30.47231408 & 0.136929674 & Cause \\
FNF & 14.8968351 & 15.09099122 & 29.98782632 & -0.194156118 & Effect \\
PA & 15.9585139 & 14.15430864 & 30.11282253 & 1.804205254 & Cause \\
ALU & 14.6264928 & 14.96379252 & 29.59028532 & -1.006092356 & Effect \\
INM & 15.9889881 & 15.63258515 & 31.62157322 & 0.356402914 & Cause \\
COS & 14.6290728 & 16.00079232 & 30.62986508 & -1.371719554 & Effect \\
RNA & 14.2594621 & 15.26612865 & 29.52559071 & -1.006666601 & Effect \\
SC & 15.8113676 & 15.66241172 & 31.47377932 & 0.148955873 & Cause \\
\hline
\end{tabular}

\section{Conclusions}

This paper has made an attempt to identify, evaluate the landfill site selection criteria, prioritise them and examine the relationship amongst these criteria and the degree to which they affect or are affected by one another, using an integrated fuzzy-Delphi-fuzzy-AHP-DEMATEL methodology. The study identifies a minimal optimal set of criteria, which reduces the time taken in the decision making process. The developed methodology effectively takes into account the uncertain, subjective and linguistic data from expert opinions, providing more logical and precise results. Our proposed methodology easily quantifies these types of data. It includes an effective method to weigh the criteria and to find the optimal solution.

The FDM widely gathers information concerning various aspects and effectively conducts the vagueness and imprecision within the experts' judgments in order to identify the critical evaluation criteria for obtaining the weights of each criterion. The fuzzy-AHP, determines the ranking of the evaluation criteria, and prioritise them. The DEMATEL, objectively determines the inter-dependent relationship among the criteria. The impact direction map drawn by DEMATEL help decision makers to indicate which dimension and criterion is the dispatcher that influences other dimensions and criteria in a system.

From the result of DEMATEL, it is clear that sensitive areas have highest degree of relationship with other criteria, and receives maximum influence from other landfill site selection dimensions. Soil and topography comes out to be a dimension having highest degree of effect.

The main findings of this research have proved that Fuzzy based AHP, and DEMATEL is a useful tool to gain a better understanding of the problem, and to help decision makers to make their decision process traceable and reliable. Moreover, this approach helps decision makers undertake a sound reflection of the siting problem. Therefore, they can select the best site based on their own facilities. The methodology described in this study is, an efficient approach for landfill site selection in conflicting opinion situations when stakeholders are not convinced that only one group of criteria plays the relative importance.

Thus, the proposed method presented in this paper can be applied to optimum landfill site selection for municipal solid waste. Furthermore, it was found that the suggested analytical procedure, can effectively handle problem of selection with multi-faceted factors.

\section{References}

Adamides ED, Mitropoulos P, Giannikos I, Mitropoulos I (2009) A multi-methodological approach to the development of a regional solid waste management system. J Oper Res Soc 60(6):758-770

Ahmed SA, Ali SM (2006) People as partners: facilitating people's participation in public-private partnerships for solid waste management. Habitat International 30(4):781-796

Alavi N, Goudarzi G, Babaei AA, Jaafarzadeh N, Hosseinzadeh M (2013) Municipal solid waste landfill site selection with geographic information systems and analytical hierarchy process: a case study in Mahshahr County. Iran Waste Manag Res 31(1):98-105

Aragonés-Beltrán P, Pastor-Ferrando JP, García-García F, PascualAgulló A (2010) An analytic network process approach for siting a municipal solid waste plant in the metropolitan area of Valencia (Spain). J Environ Manage 91(5):1071-1086

Aydi A, Zairi M, Dhia HB (2013) Minimization of environmental risk of landfill site using fuzzy logic, analytical hierarchy process, and weighted linear combination methodology in a geographic information system environment. Environ Earth Sci 68(5): 1375-1389

Babalola A, Busu I (2011) Selection of landfill sites for solid waste treatment in Damaturu Town-using GIS techniques. J Environ Protection 2(01): 1-10

Baban SM, Flannagan J (1998) Developing and implementing GISassisted constraints criteria for planning landfill sites in the UK. Plan Pract Res 13(2):139-151 
Chang DY (1996) Applications of the extent analysis method on fuzzy AHP. Eur J Oper Res 95(3):649-655

Chang NB, Wei YL (2000) Siting recycling drop-off stations in urban area by genetic algorithm-based fuzzy multiobjective nonlinear integer programming modeling. Fuzzy Sets Syst 114(1):133-149

Chang NB, Parvathinathan G, Breeden JB (2008) Combining GIS with fuzzy multicriteria decision-making for landfill siting in a fast-growing urban region. J Environ Manage 87(1):139-153

Chau KW (2005) Prototype expert system for site selection of a sanitary landfill. Civil Engineering and Environmental Systems 22(4):205-215

Cheng S, Chan CW, Huang GH (2002) Using multiple criteria decision analysis for supporting decisions of solid waste management. J Environ Sci Health Part A 37(6):975-990

Chiueh PT, Lo SL, Chang CL (2008) A GIS-based system for allocating municipal solid waste incinerator compensatory fund. Waste Manag 28(12):2690-2701

Eiselt HA (2006) Locating landfills and transfer stations in Alberta. INFOR 44(4):285-298

Eiselt HA, Marianov V (2014) A bi-objective model for the location of landfills for municipal solid waste. Eur $\mathrm{J}$ Oper Res 235(1):187-194

Erkut E, Moran SR (1991) Locating obnoxious facilities in the public sector: an application of the analytic hierarchy process to municipal landfill siting decisions. Socio-Economic Planning Sciences 25(2):89-102

Erkut E, Neuman S (1989) Analytical models for locating undesirable facilities. Eur J Oper Res 40(3):275-291

Eskandari M, Homaee M, Mahmodi S (2012) An integrated multi criteria approach for landfill siting in a conflicting environmental, economical and socio-cultural area. Waste Manag 32(8): $1528-1538$

Fontela E, Gabus A (1976) The DEMATEL Observer, DEMATEL 1976 Report. Battelle Geneva Research Center, Geneva

Frantzis I (1993) Methodology for municipal landfill sites selection. Waste Manage Res 11(5):441-451

Gabus A, Fontela E (1973) Perceptions of the world problematique: Communication procedure, communicating with those bearing collective responsibility. Battelle Geneva Research Centre, Geneva

Gbanie SP, Tengbe PB, Momoh JS, Medo J, Kabba VTS (2013) Modelling landfill location using geographic information systems (GIS) and multi-criteria decision analysis (MCDA): case study Bo, Southern Sierra Leone. Appl Geog 36(1):3-12

Geneletti D (2010) Combining stakeholder analysis and spatial multicriteria evaluation to select and rank inert landfill sites. Waste Manag 30(2):328-337

Goorah SS, Esmyot ML, Boojhawon R (2009) The health impact of nonhazardous solid waste disposal in a community: the case of the Mare Chicose landfill in mauritius. J Environ Health 72(1):48-54

Gorsevski PV, Donevska KR, Mitrovski CD, Frizado JP (2012) Integrating multi-criteria evaluation techniques with geographic information systems for landfill site selection: a case study using ordered weighted average. Waste Manag 32(2):287-296

Hale TS, Moberg CR (2003) Location science research: a review. Ann Oper Res 123(1-4):21-35

Hokkanen J, Salminen P (1997) Choosing a solid waste management system using multicriteria decision analysis. Eur J Oper Res 98(1):19-36

Hori S, Shimizu Y (1999) Designing methods of human interface for supervisory control systems. Control Eng Pract 7(11):1413-1419

Ishikawa A, Amagasa M, Shiga T, Tomizawa G, Tatsuta R, Mieno H (1993) The max-min Delphi method and fuzzy Delphi method via fuzzy integration. Fuzzy Sets Syst 55(3):241-253
Kahraman C, Cebeci U, Ruan D (2004) Multi-attribute comparison of catering service companies using fuzzy AHP: the case of Turkey. Int J Prod Econ 87(2):171-184

Kim KR, Owens G (2010) Potential for enhanced phytoremediation of landfills using biosolids-a review. J Environ Manage 91(4):791-797

Kim KH, Pal R, Ahn JW, Kim YH (2009) Food decay and offensive odorants: a comparative analysis among three types of food. Waste Manag 29(4):1265-1273

Klir G, Yuan B (1995) Fuzzy sets and fuzzy logic, vol 4. Prentice Hall, New Jersey

Kontos TD, Komilis DP, Halvadakis CP (2005) Siting MSW landfills with a spatial multiple criteria analysis methodology. Waste Manag 25(8):818-832

Kouznetsova M, Huang X, Ma J, Carpenter Lessner L, DO D (2007) Increased rate of hospitalization for diabetes and residential proximity of hazardous waste sites. Environ Health Perspect 115(1):75-79

Lee YC, Hsieh YF, Guo YB (2013) Construct DTPB model by using DEMATEL: a study of a university library website. Program 47(2):155-169

Lin KM, Lin CW (2008) Cognition map of experiential marketing strategy for hot spring hotels in Taiwan using the DEMATEL method. In Natural Computation, 2008. ICNC'08. Fourth International Conference on (Vol. 1, pp. 438-442). IEEE

Looser MO, Parriaux A, Bensimon M (1999) Landfill underground pollution detection and characterization using inorganic traces. Water Res 33(17):3609-3616

Mahler CF, de Lima GSA (2003) Applying value analysis and fuzzy logic to select areas for installing waste fills. Environ Monit Assess 84(1-2):129-140

Makan A, Malamis D, Assobhei O, Loizidou M, Mountadar M (2012) Multi-criteria decision analysis for the selection of the most suitable landfill site: case of Azemmour, Morocco. Int J Manag Sci Eng Manag 7(2):96-109

Moeinaddini M, Khorasani N, Danehkar A, Darvishsefat AA (2010) Siting MSW landfill using weighted linear combination and analytical hierarchy process (AHP) methodology in GIS environment (case study: Karaj). Waste Manag 30(5):912-920

Moghaddas NH, Namaghi HH (2011) Hazardous Waste Landfill site Selection in Khorasan Razavi Province, Northeastern Iran. Arab J Geosci 4(1-2):103-113

Muttiah RS, Engel BA, Jones DD (1996) Waste disposal site selection using GIS-based simulated annealing. Comput Geosci 22(9):1013-1017

Noorderhaben N (1995) Strategic decision making. Addison-Wesley, UK

Norese MF (2006) ELECTRE III as a support for participatory decision-making on the localisation of waste-treatment plants. Land Use Policy 23(1):76-85

Queiruga D, Walther G, Gonzalez-Benito J, Spengler T (2008) Evaluation of sites for the location of WEEE recycling plants in Spain. Waste Manag 28(1):181-190

Sharifi M, Hadidi M, Vessali E, Mosstafakhani P, Taheri K, Shahoie S, Khodamoradpour M (2009) Integrating multi-criteria decision analysis for a GIS-based hazardous waste landfill sitting in Kurdistan Province, western Iran. Waste Manag 29(10):2740-2758

Shen YC, Lin GT, Tzeng GH (2012) A novel multi-criteria decisionmaking combining Decision making trial and evaluation laboratory technique for technology evaluation. Foresight 14(2):139-153

Simsek C, Kincal C, Gunduz O (2006) A solid waste disposal site selection procedure based on groundwater vulnerability mapping. Environ Geol 49(4):620-633 
Stowers CL, Palekar US (1993) Location models with routing considerations for a single obnoxious facility. Transportation Science 27(4):350-362

Sumathi VR, Natesan U, Sarkar C (2008) GIS-based approach for optimized siting of municipal solid waste landfill. Waste Manag 28(11):2146-2160

Vasiloglou VC (2004) New tool for landfill location. Waste Manage Res 22(6):427-439

Wang G, Qin L, Li G, Chen L (2009) Landfill site selection using spatial information technologies and AHP: a case study in Beijing. China. Journal of Environmental Management 90(8):2414-2421
Wu WW (2012) Segmenting critical factors for successful knowledge management implementation using the fuzzy DEMATEL method. Appl Soft Comput 12(1):527-535

Xi BD, Su J, Huang GH, Qin XS, Jiang YH, Huo SL, Yao B (2010) An integrated optimization approach and multi-criteria decision analysis for supporting the waste-management system of the City of Beijing. China. Engineering Applications of Artificial Intelligence 23(4):620-631

Yildirim V (2012) Application of raster-based GIS techniques in the siting of landfills in Trabzon Province, Turkey: a case study. Waste Manage Res 30(9):949-960 